Egyptian Journal of Rabbit Science, 28 (2): 287 -310(2018)

\title{
NUTRITIONAL EFFECT OF LINSEED OIL ON PRODUCTIVE PERFORMANCE, CARCASS CHARACTERISTICS AND BLOOD PICTURE OF GROWING RABBITS
}

\author{
A.El.M.I. El-Desoky; El-Deeb, M.M." and A.M. Alazab \\ Anim. Prod. Res. Inst., Agric. Res. Center, Dokki, Giza, Egypt. \\ * Corresponding author: Mohamed M. El-Deeb, Animal Nutrition Research \\ Department,Email: deep121eg@yahoo.com, Mobile+201223652648
}

A number of eighty growing NZW rabbits at 5 weeks age and $620 \pm 30$ g average live body weight were weighed and distributed into five experimental groups. The experiment aimed at studying the effect of linseed oil at the rate of 1,2, 3 and $4 \%$ on their productive performance, carcass characteristics, some blood parameters, T3 and T4 as well as histological changes in the liver and testis of the tested animals.

Adding linseed oil to rabbit diets at the level of $2 \%$ improved significantly $(P \leq 0.05) L B W$ compared to the control one as well as the other 3 levels of oil. The DWG showed no significant differences among the five experimental groups, except for the treatment of $2 \%$ linseed oil which significantly differed $(P \leq 0.05)$ compared to the control group and the other 3 treatments of linseed oil. The highest significant $B W G$ value $(P \leq 0.05)$ was obtained with adding $2 \%$ linseed oil to the diet, while the lowest value obtained with the $4 \%$ oil treatment, but without significant difference with other 2 oil levels or the control one. The increase in BWG came in a descending order with increasing oil \% in the diet. The amount of daily feed intake remarkably $(P \leq 0.05)$ decreased than the control one with age when diets contained 2 and $3 \%$ linseed oil. The pest $(P \leq 0.05)$ FCR (3.58) was obtained in the group of $2 \%$ linseed oil, while the worst (4.36) was recorded with adding $4 \%$ linseed oil to the diets. Live body weight at slaughtering time as well as carcass weight insignificantly differed among the five tested groups.

Adding linseed oil to the diets of tested rabbits improved carcass weight generally over that of the control one. The group fed $2 \%$ linseed oil diet gave the highest carcass weight. Regarding weights of carcass organs, i.e. head, heart, abdominal fat and back quarters, except back quarters yield, showed no significant differences among 
the 5 different treatments. Weights of liver, kidney and testis and their yield as well as dressing percentage and back quarters yield noticeably increased $(P \leq 0.05)$ in the group of $2 \%$ linseed oil diet compared to the control one and other 3 linseed oil treatment groups.

Diet supplemented with linseed oil generally increased blood $T P, A l b ., H D L, L D L, T 3$ and T4 values compared to the control group, while it decreased glob. and cholesterol as well as TG in the two high levels of oil supplementation only. The experimental dietary treatments showed beneficial effect of omega-3-PUFA on liver and testis structures of rabbits fed diet supplemented with linseed oil at the rate of 2 and 3\% since it did not show any abnormality in the histological structure of both organs.

Conclusively, on the light of the aforementioned results, it could be concluded that addition of linseed oil to growing rabbit diets at the rate of 2 followed by $3 \%$ resulted in lowering daily feed intake accompanied by improved feed conversion ratio and increase in body weight gain without adverse effects on hematological aspects. Moreover, the same treatments induced the most noticeable changes in carcass characteristics as well as structural changes in the histology of both liver and testis of males.

Keywords: Linseed oil, growth performance, blood parameters, liver, testis, histology.

In the last decade, human nutrition became one of the most important issues because of its direct relation to human health which threatened with the century common diseases. This might result from the imbalance of omega-3polyunsaturated fatty acids ( $\Omega$-3-PUFA) intake in human foods due to usage of animal feeds rich in grains containing $\Omega$-6-PUFA resulting meat production rich in $\Omega$-6-PUFA and poor in $\Omega$-3-PUFA (Simopoulos, 2000).

Researchers has been focused to develop feeding strategies aimed at increasing the value of rabbit meat as a functional food throughout including $\Omega$-3-PUFA in their diets since, according to Food and Agriculture Organization/World Health Organization (FAO/WHO, 1994), it is essential to increase the $\Omega-3$ and decrease the $\Omega-6$ fatty acid intake in order to have a balanced $\Omega-6$ and $\Omega-3$ intake (Simopoulos, 2008). In that sense, functional food products enriched with $\Omega$-3-PUFA in Europe and USA has increased in the last years. So, a demand on producing healthy meat (meat with low saturated fatty acids "FAs" and high unsaturated FAs levels) increased. An 
extensive research work has been focused on lipid metabolism and shown that rabbits as well as mammals lack the ability to synthesize some of the essential lipids such as omega-3 $(\Omega 3)$ and consequently they must be supplemented to their diets (Okab et al., 2017).

One of the vegetable oils advantages, it considered a rich source of essentially polyunsaturated fatty acids (PUFA; Baldini et al., 2000; Calvani and Benatti, 2003). Supplying refined vegetable oils to mammalian rations has been observed to have positive effects on growth rate, carcass traits and meat composition (Whitney et al., 2000 and Vieira et al., 2006). Accordingly, attempts made for increasing the $\Omega-3$-PUFA content in rabbit meat through supplementing diets with vegetable oil or raw materials rich in $\Omega$-3-PUFA content, e.g. linseed oil, which considered one of the most concentrated sources of $\Omega$-3-PUFA, especially $\alpha$-linolenic acid (Scheideler, 1998). Linseed oil is a rich source of oleic (C18:1n-9;12-20\%), linoleic (C18:2n-6;20-24\%) and linolenic acid (C18:3n-3;36-42\%) unsaturated fatty acids (Flachowsky et al., 1998). Dalle Zotte (2002) stated that rabbits as well as monogastric animals are capable of incorporating dietary fatty acids into adipose tissue and intramuscular fats, which making it possible to modify the fatty acids profile of rabbits' meat through the planned use of unsaturated dietary fat sources. Corino et al. (2007) noticed that dietary conjugated linoleic acid (CLA) significantly increased the proportion of saturated fatty acids (SFA) at the expense of monounsaturated fatty acids (MUFA) in intramuscular and depot fat of rabbits. Belury (2002) suggested that this could be attributed to the depression of the activity of stearoyl-CoA desaturase by CLA. Peiretti (2012) found that feeding flaxseed oil in rabbits diet resulted in increased unsaturated fatty acids whereas saturated fatty acids were decreased.

Focusing on reproductive level, Wathes et al. (2007) reported that essential fatty acid deficiency leads to degeneration of the testis with concomitant infertility. Accordingly, it is well established also that PUFA are precursor molecules of different hormones (steroid and prostaglandin) that regulate the ovarian activity, the embryo implantation or the parturition time among other physiological processes. Moreover, dietary PUFA can alter the lipidemic profile affecting the gene expression that regulates the metabolism and increases peroxidation. Such effects correlated to the fact that there are three main types of omega-3 fatty acids involved in mammals' physiology, i.e. $\alpha$-linolenic acid (ALA), eicosapentaenoic acid (EPA) and docosahexaenoic acid (DHA) (Rizos et al., 2013). Sugasini and Lokesh (2017) mentioned that linseed oil contributes to testis development and steroidogenesis, since it contains up to $50 \%$ n-3 PUFAs, especially the ALA that can be converted into 
EPA and DHA through the alternating steps of elongation and desaturation involving ELOVL and FADS enzymes in mammals. According to ElMoghazy et al. (2014), several investigations have shown that consumption of oils rich in long-chain omega-3 polyunsaturated fatty acids stimulates immune functions and of effectiveness in growing rabbit diets on nutrients utilization and productive performance without negative impacts on the blood plasma analysis and histopathological changes on rabbit organs.

Generally, the desired change in rabbits planned by researchers as a response to dietary treatments depends on animal age, length of feeding period as well as on the level of supplementation (Corino et al., 2002, 2003 \& 2007). Cavani et al. (2009) found that the administration of enriched diets during the last two weeks of rabbit fattening period was effective in increasing the polyunsaturated fatty acids ( $\Omega-3$-PUFA) content of its meat.

The present study aimed at investigating the effect of different levels of linseed oil in the diets of growing NZW rabbits on growth performance, carcass traits and blood picture. Histological studies for the probable changes in bucks' liver and testis were also considered.

\section{MATERIALS AND METHODS}

\section{Experimental design and diets:}

This study was carried out in a private rabbits farm at Dekkrns, Dakahlia Governorate, Egypt during winter season of 2016. A number of $80 \mathrm{New}$ Zealand White rabbits (NZW) at 5 weeks of age and $620 \pm 30 \mathrm{~g}$ average live body weight was weighed and distributed into five experimental groups. Each treatment group was consisted of 4 replicates of 4 rabbits each. Rabbits were reared under similar hygienic, environmental and managerial conditions. Each group of rabbits was fed one of five diets containing different level of linseed oil $(0,1 \%, 2 \%, 3$ and $4 \%)$ (Table 1). Rabbits were housed in galvanized cages in well-ventilated pens (4 rabbits each). Each cage contains a stainless-steel nipple for drinking and a feeder allowing to recorded feed intake for rabbits. Fresh water and pelleted diets were offered ad libitum throughout the experimental period from the $5^{\text {th }}$ to the $14^{\text {th }}$ week of age.

\section{Growth measurements:}

Live body weight (LBW) of rabbits was recorded at 5, 8, 11 and 14 weeks of age. While, daily weight gain (DWG), body weight gain (BWG), daily feed intake (DFI) and feed conversion ratio (FCR) were calculated at 5-8, 8-11, 11-14 and 5-14 weeks of age. 
Table 1: The composition and calculated analysis of the formulated diets during the experimental period.

\begin{tabular}{|l|c|c|c|c|c|}
\hline \multirow{2}{*}{ Ingredients \# } & \multicolumn{5}{|c|}{ Treatment groups } \\
\cline { 2 - 6 } & Control & $\begin{array}{c}\mathbf{1 \%} \\
\text { Lin. Oil }\end{array}$ & $\begin{array}{c}\mathbf{2 \%} \\
\text { Lin. Oil }\end{array}$ & $\begin{array}{c}\mathbf{3 \%} \\
\text { Lin. Oil }\end{array}$ & $\begin{array}{c}\mathbf{4 \%} \\
\text { Lin. Oil }\end{array}$ \\
\hline Yellow corn & 16.0 & 12.0 & 10.0 & 6.0 & 3.0 \\
\hline Barley & 13.5 & 13.5 & 13.5 & 13.5 & 13.5 \\
\hline Wheat bran & 20.0 & 22.0 & 22.0 & 24.0 & 25.0 \\
\hline $\begin{array}{l}\text { Soybean meal } \\
\text { protein) }\end{array}$ & 12.0 & 12.0 & 12.0 & 12.0 & 12.0 \\
\hline Alfalfa hay & 32.0 & 32.0 & 32.0 & 32.0 & 32.0 \\
\hline Olive meal & 4.0 & 5.0 & 6.0 & 7.0 & 8.0 \\
\hline Dicalcium Phosphate & 1.2 & 1.2 & 1.2 & 1.2 & 1.2 \\
\hline Lime stone & 0.7 & 0.7 & 0.7 & 0.7 & 0.7 \\
\hline Premix. Min. \& Vit.* & 0.3 & 0.3 & 0.3 & 0.3 & 0.3 \\
\hline Salt & 0.3 & 0.3 & 0.3 & 0.3 & 0.3 \\
\hline Linseed oil (\%) & 0.0 & 1.0 & 2.0 & 3.0 & 4.0 \\
\hline Total & 100 & 100 & 100 & 100 & 100 \\
\hline Calculated chemical analysis of diets on $\mathbf{D M b a s i s}(\boldsymbol{\%}) * * *$ & & \\
\hline ME kcal/kg & 2742 & 2732 & 2746 & 2737 & 2738 \\
\hline CP (\%) & 17.09 & 17.15 & 17.08 & 17.14 & 17.14 \\
\hline CF (\%) & 12.73 & 13.09 & 13.29 & 13.66 & 13.92 \\
\hline EE (\%) & 3.06 & 4.05 & 5.04 & 6.03 & 7.02 \\
\hline Calcium & 1.27 & 1.30 & 1.32 & 1.34 & 1.37 \\
\hline Available Phosphorus & 0.50 & 0.51 & 0.51 & 0.51 & 0.50 \\
\hline Methionine & 0.30 & 0.31 & 0.30 & 0.31 & 0.31 \\
\hline Price, L.E/Kg & 2.55 & 2.65 & 2.76 & 2.86 & 2.97 \\
\hline
\end{tabular}

* Each $1 \mathrm{Kg}$ of the Premix contains: Vitamin A 2 MIU, Vit. $\mathrm{D}_{3} 150000$ IU, Vit. E 8.33 g, Vit. K 0.33 g, Vit. $B_{1} 1$ g, Vit. $B_{2} 1.09$ g, Vit. $B_{6} 0.33$ g, Vit. $B_{5} 8.33$ g, Vit. $B_{12} 1.7$ mg, Pantothenic acid $3.33 \mathrm{~g}$, Folic acid $0.83 \mathrm{~g}$, Biotin $33 \mathrm{mg}$, Choline chloride $20 \mathrm{~g}, \mathrm{Mg} 66.79$ g, Zn 11.79 g, Fe 12.5 g, Cu 0.5 g, I 0.3 g, Se 16.6 mg, Co $1.33 \mathrm{mg}$ and carrier $\mathrm{CaCO}_{3}$ up to $1000 \mathrm{~g}$.

*** According to NRC (1977).

\# Feed constituents were bought from the local market; ground, mixed and pelleted (size 4 x 12 $\mathrm{mm})$.

\section{Carcass traits measurements:}

After 63 days of treatment (at 98 days of age), rabbits were fasted for 18 hours before slaughtering, weighed individually as a pre-slaughter weight and three bucks from each treatment group were randomly selected and handily slaughtered. Data of final live body weight as well as carcass parts (carcass 
weight, head, liver, heart, abdominal fat, kidney, testes and back quarters) were recorded. Dressing percentage as well as percentage of all carcass parts relative of pre-slaughter weight were calculated.

\section{Blood profile measurements:}

During slaughtering process, blood samples from each rabbit were collected in heparinized test tubes and centrifuged at $3500 \mathrm{rpm}$ for 15 minutes to obtain blood plasma which stored at $-20^{\circ} \mathrm{C}$ until analysis. Plasma were assigned for determination of some immunological indicators e.g. total protein (TP), globulin (Glob.) and albumin (Alb.). The levels of T3 and T4 as an indicator for feed utilization were also measured. Moreover, cholesterol, triglycerides (TG), high-density lipids (HDL) and low-density lipids (LDL) were determined. The level of T3 and T4 performed using Biocheck Kits Inc. (USA) catalog no BC-1005 and BC-1008 using monoclonal antibody. The other tested blood parameters were assayed calorimetrically using commercial kits (Diamond Diagnostics, Egypt) according to the procedure outlined by the manufacturer.

\section{Histological examintaion technique:}

After slaughtering, liver and testicular specimens were obtained from 15 healthy NZW bucks representing the five supplementation groups. Tissue specimens were taken and immediately fixed in a $10 \%$ formalin solution, embedded in paraffin blocks, sliced into $5 \mu \mathrm{m}$ thickness, mounted onto glass slides, and stained with hematoxylin and eosin, and Masson trichrome stain according to Bancroft et al. (2013).

\section{Statistical analysis:}

Data was statistically analyzed by using computer program of SAS (2000) using the general linear models (GLM). Significance among treatment means were tested at $(\mathrm{P} \leq 0.05)$ using Duncan's New Multiple Rang Test (Duncan, 1955).

\section{RESULTS AND DISCUSSION}

\section{Growth measurements:}

Data in Table 2 showed that, during the experimental period (about 9 weeks), adding linseed oil to rabbit diets at the level of $2 \%$ improved significantly $(\mathrm{P} \leq 0.05) \mathrm{LBW}(\mathrm{g})$ compared to the control one as well as the other 3 levels of oil. Such differences were not significant between the control group and either the 3 oil groups or among them. 
Table 2: Effect of dietary levels of linseed oil on live body weight (LBW) and body weight gain (DWG) at different ages of NZW rabbits.

\begin{tabular}{|c|c|c|c|c|c|c|c|c|}
\hline \multirow{2}{*}{ Treatments } & \multicolumn{4}{|c|}{ LBW (g) } & \multicolumn{4}{|c|}{ DWG (g) } \\
\hline & 5 & 8 & 11 & 14 & $5-8$ & 8-11 & 11-14 & $5-14$ \\
\hline Control & 635.00 & $1202.49^{\mathrm{b}}$ & $1806.66^{\mathrm{b}}$ & $2177.50^{\mathrm{b}}$ & $27.02^{\mathrm{b}}$ & $28.77^{\mathrm{ab}}$ & $17.66^{\mathrm{a}}$ & $24.48^{\mathrm{b}}$ \\
\hline Lin. Oil 1\% & 634.16 & $1177.50^{\mathrm{b}}$ & $1757.08^{b}$ & $2142.50^{b}$ & $25.87^{\mathrm{b}}$ & $27.60^{b}$ & $18.35^{\mathrm{a}}$ & $23.94^{\mathrm{b}}$ \\
\hline Lin. Oil 2\% & 633.33 & $1287.50^{\mathrm{a}}$ & $1931.66^{\mathrm{a}}$ & $2308.33^{\mathrm{a}}$ & $31.15^{\mathrm{a}}$ & $30.67^{\mathrm{a}}$ & $17.93^{\mathrm{a}}$ & $26.58^{\mathrm{a}}$ \\
\hline Lin. Oil 3\% & 618.33 & $1204.16^{\mathrm{b}}$ & $1782.50^{\mathrm{b}}$ & $2161.66^{b}$ & $27.89^{\mathrm{b}}$ & $27.54^{b}$ & $18.05^{\mathrm{a}}$ & $24.49^{\mathrm{b}}$ \\
\hline Lin. Oil 4\% & 622.50 & $1200.83^{b}$ & $1774.58^{\mathrm{b}}$ & $2085.00^{\mathrm{b}}$ & $27.54^{\mathrm{b}}$ & $27.32^{\mathrm{b}}$ & $17.78^{b}$ & $23.21^{\mathrm{b}}$ \\
\hline SEM & 10.58 & 26.20 & 35.38 & 34.68 & 1.04 & 0.87 & 0.61 & 0.45 \\
\hline Sig. test & NS & * & $*$ & $*$ & * & * & $*$ & $*$ \\
\hline
\end{tabular}

The DWG (g) showed no significant differences among the five experimental groups during the tested periods, except for the treatment of $2 \%$ linseed oil which significantly differed $(\mathrm{P} \leq 0.05)$ compared to the control group and the other 3 treatments of linseed oil.

These results obtained herein are in harmony with Saleh et al. (2013) who found that although feed intake was decreased significantly $(\mathrm{P}<0.05)$ by the dietary linseed oil and organic selenium, body weight gain was significantly $(\mathrm{P}<0.05)$ increased. Also, Delgado (2017) found that linseed oil as a source of fatty acids in rabbit diets improved both LBW and average daily gain. Okab et al. (2017), using different sources of $\Omega$-3-PUFA in rabbit diets, found that body weight gain of bucks fed either 3\% soybean oil or $1.5 \%$ soybean oil $+1.5 \%$ sunflower oil showed $(\mathrm{P}<0.05)$ increases, whereas no effects $(\mathrm{P}>0.05)$ was observed on the bucks fed 3\% sunflower oil, compared to bucks in the control group.

On the other hand, Trebušak et al. (2011), Omer et al. (2013), Zeweil et al. (2016) and El-Desoky et al. (2018) recorded that there were no significant differences in the initial and final body weight and also in the body weight gain as well as daily weight gain of rabbits fed linseed oil diets.

Regarding BWG (Table 3), it is clear that it followed the same trend of LBW, since the highest significant $B W G$ value $(P \leq 0.05)$ was obtained with adding $2 \%$ linseed oil to the diet, while the lowest value was obtained with the $4 \%$ oil treatment, but without significant difference with other 2 oil levels or the control one. The increment in BWG came in a descending order advancement with increasing oil \% in the diet. The highest significant BWG value $(\mathrm{P} \leq 0.05)$ obtained with adding $2 \%$ linseed oil to the diet, while the 
Table 3: Effect of dietary levels of linseed oil on daily weight gain (BWG), daily feed intake gain (DFI) and feed conversion ratio (FCR) at different ages of NZW rabbits.

\begin{tabular}{|c|c|c|c|c|c|c|c|c|}
\hline \multirow[b]{2}{*}{ Parameters } & \multirow[b]{2}{*}{$\begin{array}{c}\text { Age } \\
\text { (weeks) }\end{array}$} & \multicolumn{7}{|c|}{ Treatment groups } \\
\hline & & Control & $\begin{array}{c}\text { Lin. Oil } \\
1 \%\end{array}$ & $\begin{array}{c}\text { Lin. Oil } \\
2 \%\end{array}$ & $\begin{array}{c}\text { Lin. Oil } \\
\mathbf{3 \%}\end{array}$ & $\begin{array}{c}\text { Lin. Oil } \\
4 \%\end{array}$ & SEM & $\begin{array}{l}\text { Sig. } \\
\text { test }\end{array}$ \\
\hline \multirow{4}{*}{$\begin{array}{c}\text { BWG } \\
(\mathrm{g})\end{array}$} & $5-8$ & $567.50^{b}$ & $543.33^{b}$ & $654.16^{\mathrm{a}}$ & $585.83^{\mathrm{b}}$ & $578.33^{b}$ & 21.96 & $*$ \\
\hline & $8-11$ & $604.16^{\mathrm{ab}}$ & $579.58^{b}$ & $644.16^{\mathrm{a}}$ & $578.33^{b}$ & $573.75^{b}$ & 18.28 & $*$ \\
\hline & 11-14 & $370.83^{\mathrm{a}}$ & $385.41^{\mathrm{a}}$ & $376.66^{\mathrm{a}}$ & $379.16^{\mathrm{a}}$ & $310.41^{b}$ & 12.82 & $*$ \\
\hline & $5-14$ & $1542.50^{\mathrm{b}}$ & $1508.33^{b}$ & $1675.00^{\mathrm{a}}$ & $1543.33^{b}$ & $1462.50^{\mathrm{b}}$ & 28.54 & $*$ \\
\hline \multirow{4}{*}{$\begin{array}{c}\text { DFI } \\
\text { (g/day) }\end{array}$} & $5-8$ & $68.88^{\mathrm{ab}}$ & $70.11^{\mathrm{a}}$ & $66.34^{\mathrm{ab}}$ & $67.93^{\mathrm{ab}}$ & $65.07^{b}$ & 1.48 & $*$ \\
\hline & $8-11$ & $100.47^{\mathrm{a}}$ & $103.33^{\mathrm{a}}$ & $92.85^{b}$ & $98.41^{\mathrm{ab}}$ & $100.39^{\mathrm{a}}$ & 2.04 & * \\
\hline & 11-14 & $137.02^{\mathrm{a}}$ & $131.42^{b}$ & $126.54^{b}$ & $130.69^{b}$ & $138.13^{\mathrm{a}}$ & 1.71 & * \\
\hline & $5-14$ & 102.12 & 101.62 & 95.25 & 87.86 & 101.20 & 5.11 & NS \\
\hline \multirow{4}{*}{ FCR } & $5-8$ & $2.55^{\mathrm{ab}}$ & $2.71^{\mathrm{a}}$ & $2.13^{\mathrm{c}}$ & $2.44^{\mathrm{b}}$ & $2.37^{\mathrm{b}}$ & 0.07 & $* *$ \\
\hline & $8-11$ & $3.49^{\mathrm{ab}}$ & $3.79^{\mathrm{a}}$ & $3.04^{b}$ & $3.57^{\mathrm{a}}$ & $3.67^{\mathrm{a}}$ & 0.17 & $*$ \\
\hline & 11-14 & $7.78^{b}$ & $7.18^{b}$ & $7.08^{b}$ & $7.50^{\mathrm{b}}$ & $7.39^{\mathrm{a}}$ & 0.29 & $*$ \\
\hline & $5-14$ & $4.17^{\mathrm{ab}}$ & $4.25^{\mathrm{ab}}$ & $3.58^{b}$ & $3.60^{\mathrm{ab}}$ & $4.36^{\mathrm{a}}$ & 0.23 & * \\
\hline
\end{tabular}

${ }^{\mathrm{a}, \mathrm{b}}$ Means in the same raw bearing different superscript are significantly different $(\mathrm{P} \leq 0.05)$. NS: Not significant, $* \mathrm{P} \leq 0.05, * * \mathrm{P} \leq 0.01$

lowest value was obtained with the $4 \%$ oil treatment, but without significant difference with other two oil levels or the control one. The amount of DFI (Table 3) remarkably $(\mathrm{P} \leq 0.05)$ decreased than the control ones during the periods from 8-11 and 11-14 weeks of age with diets contained 2 and 3\% linseed oil. While rabbits fed the control diet or 1 or $4 \%$ linseed oil recorded the highest values of DFI, which was clear during the whole experimental period (5-14 weeks) without significant differences among the 5 experimental groups. Meanwhile, data in the same Table 3 showed that the pest $(\mathrm{P} \leq 0.05)$ FCR (3.58) was obtained in the group of $2 \%$ linseed oil, while the worst (4.36) was recorded with adding $4 \%$ linseed oil to the diets without significant differences with either the control or the other 2 added oil levels.

The results in the present study came on line with those obtained by Trebušak et al. (2011) who reported that rabbits fed linseed oil recorded some differences among treatments in feed intake and feed efficiency, since they noticed that animals fed diet enriched with linseed oil showed significantly lower feed intake and consecutively had significantly higher feed efficiency. This means that animals with supplemented diet consumed significantly $(\mathrm{P}=0.0006)$ less feed than control animals for $1 \mathrm{~kg}$ weight gain. They explained the differences by the much higher fat (energy) content in the linseed diet. Similar results were obtained by Saleh et al. (2013) who reported no 
significant effect of linseed oil on feed intake of rabbits, but feed intake was significantly reduced and feed conversion ratio was improved when linseed oil mixed with organic selenium was offered for male growing NZW rabbits. Moreover, Zeweil et al. (2016) noticed that the 2\% linseed oil diets significantly $(\mathrm{P} \leq 0.05)$ decreased feed intake and significantly $(\mathrm{P} \leq 0.05)$ improved feed conversion ratio in comparison with the control.

On contrary, Okab et al. (2017) reported that neither soybean oil nor sunflower oil as sources of ( $\Omega$-3-PUFA) with different ratios in rabbit diets had a particular trend of feed conversion ratios calculated for all groups exhibited, to some extent, comparable figures.

\section{Carcass traits measurements:}

Figures in Table 4 showed that live body weight at slaughtering time as well as carcass weight insignificantly differed among the five tested groups. Adding linseed oil to the diets of tested rabbits improved carcass weight generally over that of the control ones. It is worthy noticing that the group fed $2 \%$ linseed oil diets gave the highest carcass weight. Regarding weights of carcass organs, i.e. head, heart, abdominal fat and back quarters as well as their yield, except back quarters yield, they showed no significant differences among the 5 different treatments. While, weights of liver, kidney and tests and their yield as well as dressing percentage and back quarters yield noticeably increased $(\mathrm{P}<0.05)$ in the group of $2 \%$ linseed oil diet compared to the control ones and other 3 linseed oil treatment groups. It is worth mentioning that most carcass parts (organs) followed the same trend of final live body slaughter and carcass weights, when showed higher dressing percentage of $2 \%$ group followed by $3 \%$, while the results came comparable among the other 2 oil groups and the control one without significant differences in most cases.

The results recorded in Table 4 are in agreement with several authors, e.g. Abdulkareem (2011) who found that addition of organic selenium at level $0.15 \mathrm{mg} / \mathrm{kg}$ to growing rabbit diets resulted in significant $(\mathrm{P} \leq 0.01)$ increase in dressed percentage and significant $(\mathrm{P} \leq 0.01)$ decrease in head percentage. Also, Salama (2011) found that adding $2 \%$ linseed oil to rabbit diets resulted in higher $(\mathrm{P}<0.01)$ carcass percentage than other treated groups. Moreover, Saleh et al. (2013) reported that carcass weight, dressing percentage and liver weight were increased; however, abdominal fat weight was decreased significantly $(\mathrm{P}<0.05)$ by dietary supplementation of linseed oil plus organic selenium to rabbit diets. 
Table 4: Carcass characteristics of rabbits and carcass yield (\% carcass weight) of rabbits fed different levels of linseed oil.

\begin{tabular}{|c|c|c|c|c|c|c|c|}
\hline \multirow[b]{2}{*}{ Parameters } & \multicolumn{6}{|c|}{ Treatment groups } & \multirow[b]{2}{*}{$\begin{array}{l}\text { Sig. } \\
\text { test }\end{array}$} \\
\hline & Control & $\begin{array}{l}\text { Lin. Oil } \\
1 \%\end{array}$ & $\begin{array}{c}\text { Lin. Oil } \\
2 \%\end{array}$ & $\begin{array}{l}\text { Lin. Oil } \\
3 \%\end{array}$ & $\begin{array}{l}\text { Lin. Oil } \\
4 \%\end{array}$ & SEM & \\
\hline Live weight (g) & 2290.00 & 2286.25 & 2317.50 & 2332.50 & 2297.50 & 84.78 & NS \\
\hline Carcass weight & 1472.50 & 1475.00 & 1515.00 & 1490.00 & 1440.00 & 61.60 & $\mathrm{NS}$ \\
\hline \multirow{2}{*}{$\begin{array}{r}\text { Head weight, } g \\
\%\end{array}$} & 143.75 & 128.75 & 136.25 & 140.00 & 141.25 & 5.73 & \multirow{2}{*}{ NS } \\
\hline & 9.79 & 8.75 & 8.98 & 9.44 & 9.81 & 0.36 & \\
\hline \multirow{2}{*}{ Liver weight, $\mathbf{g}$} & $66.25^{b}$ & $70.00^{\mathrm{ab}}$ & $85.00^{\mathrm{a}}$ & $85.00^{\mathrm{a}}$ & $82.50^{\mathrm{ab}}$ & 5.23 & \multirow{2}{*}{$*$} \\
\hline & $48^{\mathrm{b}}$ & $4.75^{\mathrm{b}}$ & $5.60^{\mathrm{a}}$ & $5.71^{\mathrm{a}}$ & $5.72^{\mathrm{a}}$ & 0.27 & \\
\hline \multirow{2}{*}{$\begin{array}{r}\text { Heart weight, } g \\
\%\end{array}$} & & 5.87 & 5.98 & 634 & 7.04 & 0.49 & \multirow{2}{*}{ NS } \\
\hline & 0.44 & 0.40 & 0.39 & 0.42 & 0.48 & 0.03 & \\
\hline \multirow{2}{*}{$\begin{array}{r}\text { Abdominalfat weight,g } \\
\%\end{array}$} & 28.10 & 19.72 & 38.08 & 24.34 & 39.65 & 8.24 & \multirow{2}{*}{ NS } \\
\hline & 1.88 & 1.32 & 2.46 & 1.66 & 2.73 & 0.52 & \\
\hline \multirow{2}{*}{$\begin{array}{r}\text { Kidney weight, g } \\
\%\end{array}$} & $13.13^{b}$ & $12.89^{\mathrm{b}}$ & $14.43^{\mathrm{ab}}$ & $13.50^{b}$ & $15.90^{\mathrm{a}}$ & 0.70 & \multirow{2}{*}{$*$} \\
\hline & $0.89^{\mathrm{b}}$ & $0.87^{\mathrm{b}}$ & $0.95^{\mathrm{ab}}$ & $0.91^{\mathrm{b}}$ & $1.10^{\mathrm{a}}$ & 0.05 & \\
\hline \multirow{2}{*}{$\begin{array}{r}\text { Testes weight, } \mathrm{g} \\
\%\end{array}$} & $11.56^{\mathrm{bc}}$ & $10.36^{\mathrm{c}}$ & $14.30^{\mathrm{a}}$ & $13.37^{\mathrm{a}}$ & $12.68^{\mathrm{ab}}$ & 0.55 & \multirow{2}{*}{ ** } \\
\hline & $0.78^{\mathrm{bc}}$ & $0.70^{c}$ & $0.94^{\mathrm{a}}$ & $0.90^{\mathrm{ab}}$ & $0.88^{\mathrm{ab}}$ & 0.04 & \\
\hline \multirow{2}{*}{ Back quarters, g } & 492.50 & 495.00 & 511.25 & 531.25 & 473.75 & 23.21 & \\
\hline & $33.47^{\mathrm{ab}}$ & $33.58^{\mathrm{ab}}$ & $33.65^{\mathrm{ab}}$ & $35.80^{\mathrm{a}}$ & $32.83^{b}$ & 0.78 & \\
\hline Dressing percentage* & $63.21^{\mathrm{ab}}$ & $64.46^{\mathrm{ab}}$ & $65.37^{\mathrm{a}}$ & $63.82^{\mathrm{ab}}$ & $62.65^{\mathrm{b}}$ & 0.67 & $*$ \\
\hline
\end{tabular}

${ }^{\mathrm{a}, \mathrm{b}}$ Means in the same raw bearing different superscript are significantly different $(\mathrm{P} \leq 0.05)$.

* Dressing percentage $=100 \times($ Carcass weight + Head weight + Giblets weight $) /$ Live body weight,

Where, Giblets weight $=$ Liver weight + Heart weight + Kidneys weight $) /$ Live body weight $\mathrm{x} 100$.

NS: Not significant, $* \mathrm{P} \leq 0.05, * * \mathrm{P} \leq 0.01$

Abdukeyum et al. (2008) suggested that PUFA present in soy lecithin may exert a protective effect on the rats' heart by improving the energy efficiency in this muscle. Also, Anderson et al. (2014) reported that diets enriched with PUFA increase human's antioxidant enzyme expression and decrease mitochondrial reactive oxygen species which may protect the spleen and increase its proportion.

Attia et al. (2018) stated that higher energy availability for protein deposition and so better rabbit carcass yield may be due to soy lecithin supplementation improving lipid metabolism in the body. In the diets with 1 or $1.5 \%$ addition of soy lecithin, the higher PUFA content than SFA content leads to higher metabolizable energy (Celebi and Utlu, 2004). The latter authors added that the liver relative weight of hens can be improved by soy lecithin inclusion to the diet since lipogenesis occurs primarily in the liver, and this effect may be correlated with enhanced lipid metabolism in this organ. In addition, PUFA present in the diets can protect hepatocytes by inhibiting liver cell peroxidation 
as shown by Qiu et al. (2012). On contrary, Peiretti and Meineri (2008) concluded that the diets did not significantly influence the carcass yield and the proportion of various carcass parts and organs of the rabbits.

The contradictions in having positive or negative impact from using $\Omega-3$ PUFA sources in rabbit diets are crucial point because such effects depend on the length of feeding period as well as on the level of supplementation (Corino et al., 2007). The form of PUFA supplementation sources also plays a vital role on such effects, since Marounek et al. (2007) found that conjugated linoleic acid (CLA) had no or limited effect on feed intake, growth, carcass traits and composition of meat of rabbits. They found also that treatment with CLA increased the proportion of saturated FA at the expense of monounsaturated FA in meat and liver. In this concern, Rodríguez (2017) found that abdominal fat of growing rabbits (at 30, 45, and $60 \mathrm{~d}$ of age) tended to be lower in enriched rabbits than in control ones and concluded that the effect of feeding rabbits on $\Omega$-3-PUFA sources take place upon the fact of continuing with the same diet during growing period supplementation which enhance beneficial long-chain $\Omega$-3-PUFA and decrease $\Omega-6 / \Omega-3$ ratio in rabbit meat and fat, being healthier for human consumption, without having negative effects on growth performance and carcass characteristics.

\section{Blood profile measurements:}

Figures 1 and 2 presented the values of some blood parameters of the tested animals in the five studied treatment groups. It seems that diet supplementation with linseed oil generally increased TP, Alb., HDL, LDL, T3 and $\mathrm{T} 4$ values compared to the control group. While oil supplementation decreased glob. and cholesterol as well as TG in the two high levels of oil supplementation only.

The obtained trend in the present study came on line with results recorded by several authors (Salama, 2011 and Trebušak et al., 2011). They concluded that addition of linseed oil at the rate of 2 or $3 \%$ in the diet had a beneficial effect on fatty acid composition of rabbit meat as it reduced the proportion of total SFA and the levels of cholesterol and triglycerides. They added that, the proportion of $\Omega$-3-PUFA and values of high density lipoprotein cholesterol (HDL-chol.) were significantly $(\mathrm{P} \leq 0.05)$ increased while, lowdensity lipoprotein cholesterol (LDL-chol.) do not show significant effect for linseed oil supplementation. Moreover, Bielanski and Kowalska (2008) reported that added linseed oil to rabbit diets resulted in favorable effect on the composition of the lipid fraction of rabbit meat, since it caused a significant 


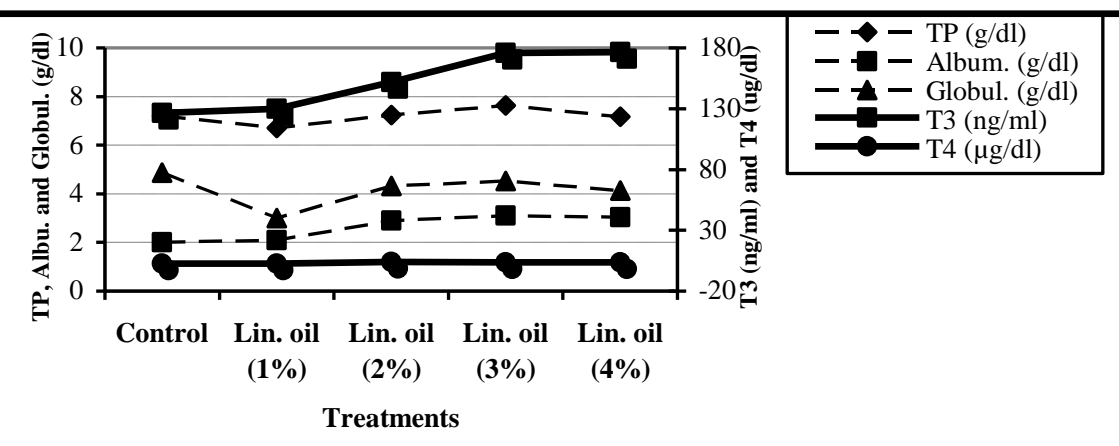

Figure 1: Some immunological and metabolic hormones indicators as affected by linseed oil supplementation in NZW rabbit diets.

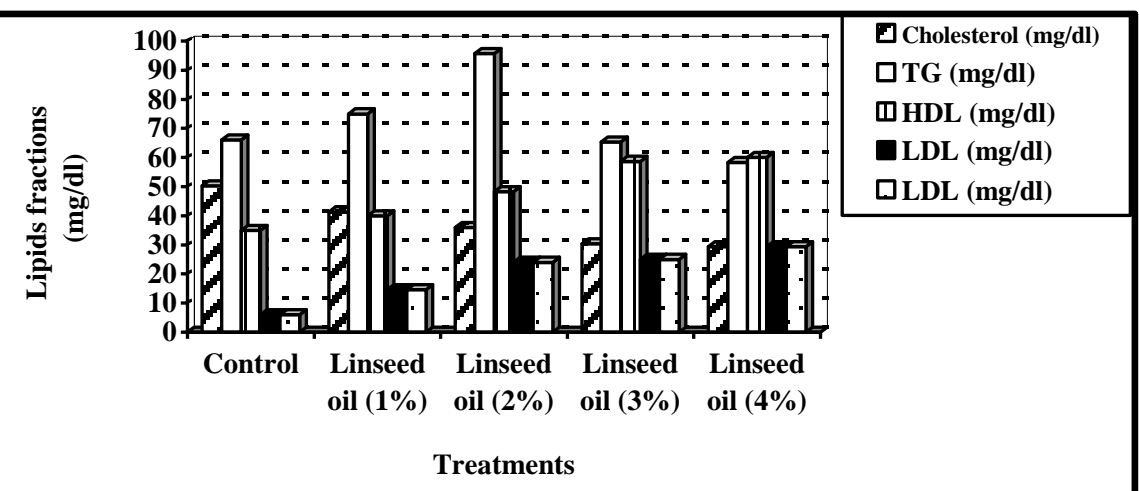

Figure 2: Levels of blood lipids and its fractions as affected by linseed oil supplementation in NZW rabbit diets.

decrease in total saturated fatty acids and an increase in polyunsaturated fatty acids ( $\Omega$-3-PUFA).

On the other hand, El-Moghazy et al. (2014) found that although feeding NZW rabbit diets supplemented with fish oil as a source of omega-3 PUFAs significantly increased total proteins, albumin and albumin/globulin ratio, it decreased significantly means of $\mathrm{T}_{3}$ level in blood plasma of fish oil treated rabbits compared with that of the basal diet and this trend was dose-dependent, while such differences were not significant regarding $\mathrm{T}_{4}$ in rabbit blood. They added that addition of fish oil had no significant effect on the thyroid hormones (T4 and TSH) of rabbits; however slightly higher values were observed in rabbits fed basal diet supplemented with 0.5 and $1.0 \mathrm{ml}$ fish oil per day/kg live body weight without statistical significance. 
El-Desoky et al. (2018) reported that the supplementation of rabbit does diets with linseed oil at the rate of $1.5,3$ and $4.5 \%$ generally tended to decrease cholesterol level compared to that of the control. The control group recorded the highest $(\mathrm{P} \leq 0.05)$ high density lipids $(\mathrm{HDL})$ values compared to other groups of linseed oil supplementation which were insignificantly differed. Supplementing does' diets with linseed oil resulted in significantly increase in tri-glycerides (TG) and the level of $3.0 \%$ linseed oil supplementation recorded the lowest $(\mathrm{P} \leq 0.05) \mathrm{TG}$ value among the other two supplemented groups at the end of the experiment.

Also, Saleh et al. (2013) showed that dietary supplementation of linseed oil with or without organic selenium decreased plasma total cholesterol and LDL, while plasma HDL was increased when organic selenium added with linseed oil to the rabbit diets. Miezeliene et al. (2011) attributed this effect to the possibility of lipolysis which was increased by selenium feeding. Moreover, Zeweil et al. (2016) reported that serum total lipids, triglycerides, total cholesterol and LDL significantly $(\mathrm{P} \leq 0.05)$ decreased due to linseed oil supplementation to rabbit diets either with organic selenium or ginger or both but, values of HDL concentration and HDL/LDL ratio were significantly $(\mathrm{P} \leq 0.05)$ increased as compared with the control group. The same authors found that serum total lipids, total cholesterol and TG were significantly $(\mathrm{P} \leq 0.01)$ reduced as a result of adding 100 or $200 \mathrm{mg}$ lycopene to growing rabbit diets in comparison with the control ones.

In this connection, Rhainds and Brissette (2004) reported that $\Omega-3$ PUFA stimulates the flow of cholesterol ester transport from peripheral tissues to the liver, where cholesterol can either be secreted via the bile duct or be used to synthesize steroid hormones.

Rodríguez (2017) explained that the changes in TG levels with adding omega-3 source to rabbit diets on the basis that TG are stripped from chylomicrons and very low-density lipoprotein cholesterol through the action of lipoprotein lipase (an enzyme that is found on the surface of endothelial cells). This enzyme digests the TG to fatty acids and monoglycerides, which can then diffuse into the cell to be oxidized, or in the case of adipocytes, to be re-synthesized into TG and stored in the cell. The same author added that the function of low-density lipoprotein cholesterol is to deliver cholesterol to cells, where it is used in membranes, or for the synthesis of steroid hormones.

It is of interest to mention that several authors demonstrated effectiveness of fish oil as a source of omega-3 PUFAs in growing rabbit diets on nutrients utilization and productive performance without negative impacts 
on the blood plasma analysis and histopathological changes on rabbit organs as discussed and reviewed by El-Moghazy et al. (2014).

\section{Histological studies for liver and testis of bucks:}

The histological examination for both liver and testis of bucks from the five experimental groups fed 1,2, 3 and $4 \%$ linseed oil compared to the control ones (Without linseed oil supplementation) is presented in the following Figures (3a-f \& 4a-f), respectively.

The obtained results in this study are in harmony with those obtained by Crowley et al. (2000) had been suspected that low dietary PUFA might be responsible for little abnormality found in the histology of the liver, but they found a beneficial effect of omega-3-PUFA on liver of rabbits fed diet supplemented with fish oil (higher in omega-3 and lower in $\omega-6 / \omega-3$ ratios) which did not show any abnormality.

Also, El-Moghazy et al. (2014) concluded that fish oil supplementation to NZW rabbit diets had no adverse effect on histological structure of liver and kidney and metabolic function. Moreover, Abu-Dief et al. (2018) concluded that omega-3 fatty acids have anti-inflammatory and anti-fibrotic effects on carbon tetrachloride (CCl4)-induced liver cirrhosis in mice. Zhang et al. (2017) demonstrated also that dietary flaxseed oil alleviated hepatic inflammation via anti-inflammatory cytokines.

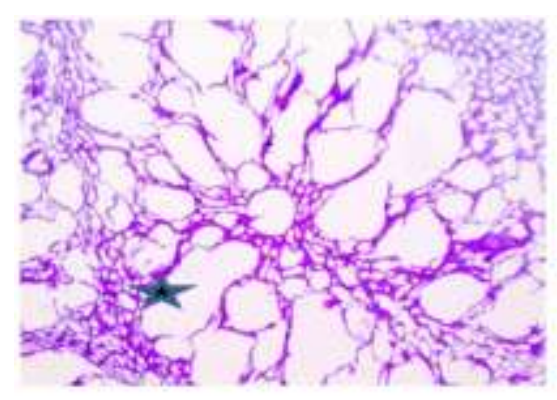

(a)

The Liver of rabbits fed $1 \%$ linseed oil in their diets showed ( $\downarrow$ ) marked telangiectasia, dilated lymphatics and edema in portal area.

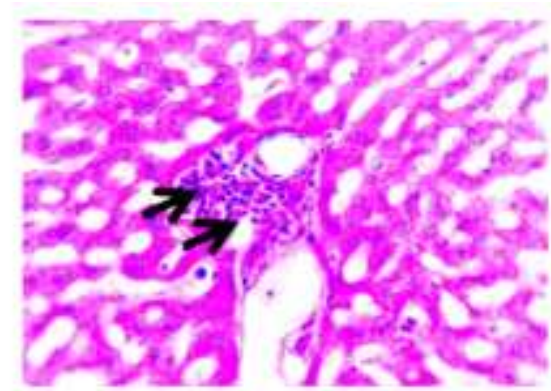

(b)

Atrophied hepatic cords with compressed more basophilic nuclei (7). Focal aggregation of mononuclear cells (MNCs) appeared in hepatic parenchyma. 


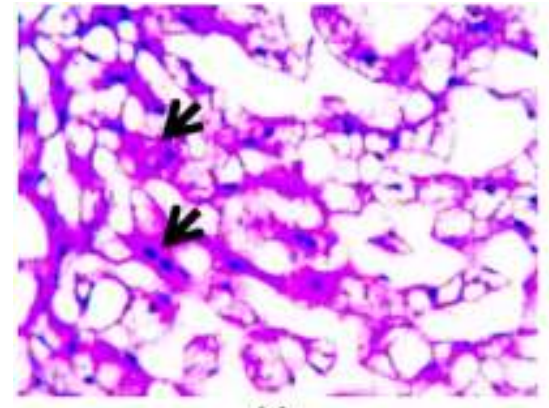

(c)

Perivascular necrosis, mild vacuolar and hydropic degeneration (2) were observed in hepatocytes.

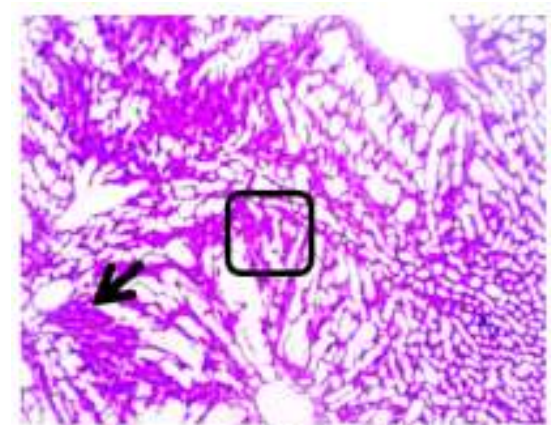

(e)

Liver of bucks in group fed diets supplemented with $3 \%$ linseed oil showed moderate telangiectasia, dilated lymphatics and edema in portal area (ロ), atrophied hepatic cords with compressed more basophilic nuclei $/$. Hydropic degeneration was also seen in some fields. Focal area of fibrosis was also present.

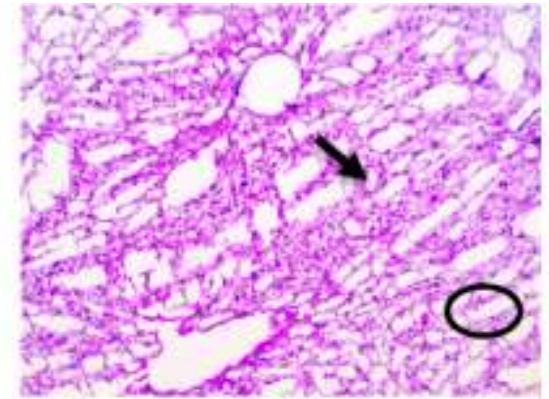

(d)

The Liver of rabbits fed $2 \%$ linseed oil in their diets showed a marked telangiectasia, dilated lymphatics and edema in portal area $\mathbf{y}$ ). Also, a marked hydropic degeneration and fatty change were found in $(D)$ hepatocytes.

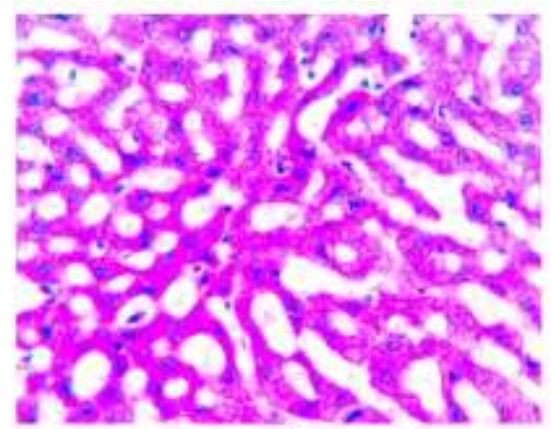

(f)

The Liver of bucks fed $4 \%$ linseed oil in their diets revealed that hepatocytes returned their normal shape.

Figure 3: Liver changes in rabbits fed different levels of linseed oil during the experimental period $(\mathrm{X} 400)$. 


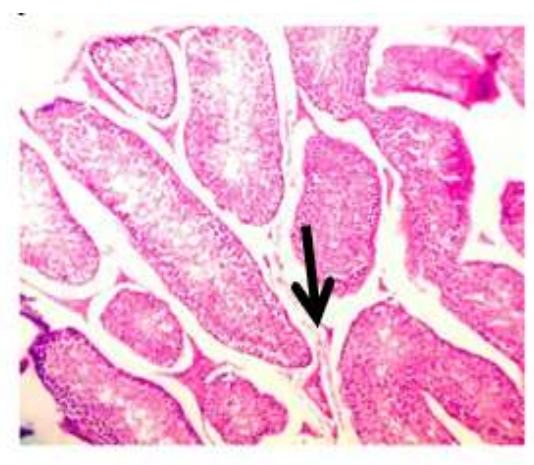

(a)

Seminiferous tubules of bucks in the control group normal in shape, lined with normal germinal epithelium organized in concentric layers and separated by interstitial connective tissue.

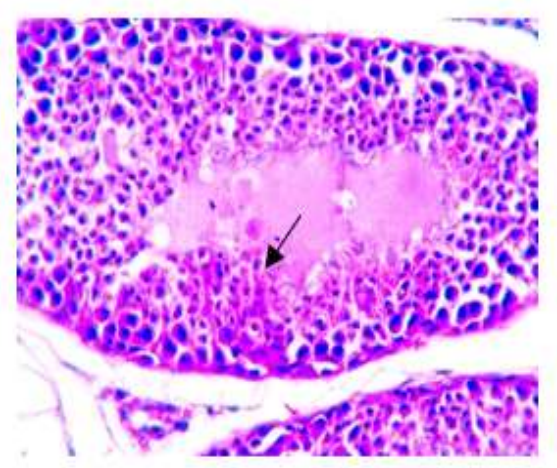

(c)

Testis of the same bucks in the $3 \%$ linseed oil group showed that most seminiferous tubules enlarged in size with increased thickness of epithelial lining ( $)$. Few seminiferous tubules were still small sized with irregular outlines but with several layers of germinal epithelium. Vacuolar degeneration and spermatocutic giant cells were observed in some seminiferous tubules. Early spermatids were degenerated and necrotized while late spermatids were absent from all seminiferous tubules. Few MNCs infiltration was observed in interstitial tissue.

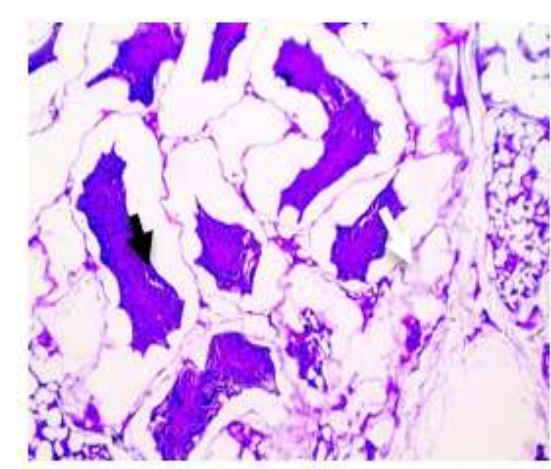

(b)

TTestis of the same bucks in $1 \%$ linseed oil group showed a small sized to atrophied seminiferous tubules with irregular outlines lined with few germinal epithelial layers and some had flattened nuclei $(\mathbf{s})$. Early and late spermatids were absent from all seminiferous tubules. Some seminiferous tubules had only spermatogonia with flattened nuclei. Hyalinized material was noticed in their Lumina. Severe interstitial edema was seen and interstitial cells of Leydig were vacuolized.

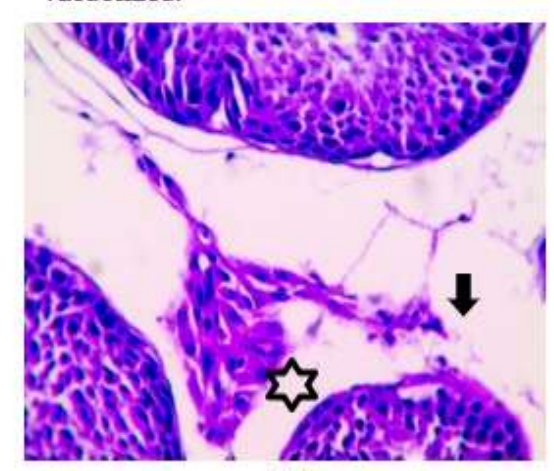

(d)

Interstitial edema decreased less than in the former slides. Interstitial cells of Leydig and round in shape. 

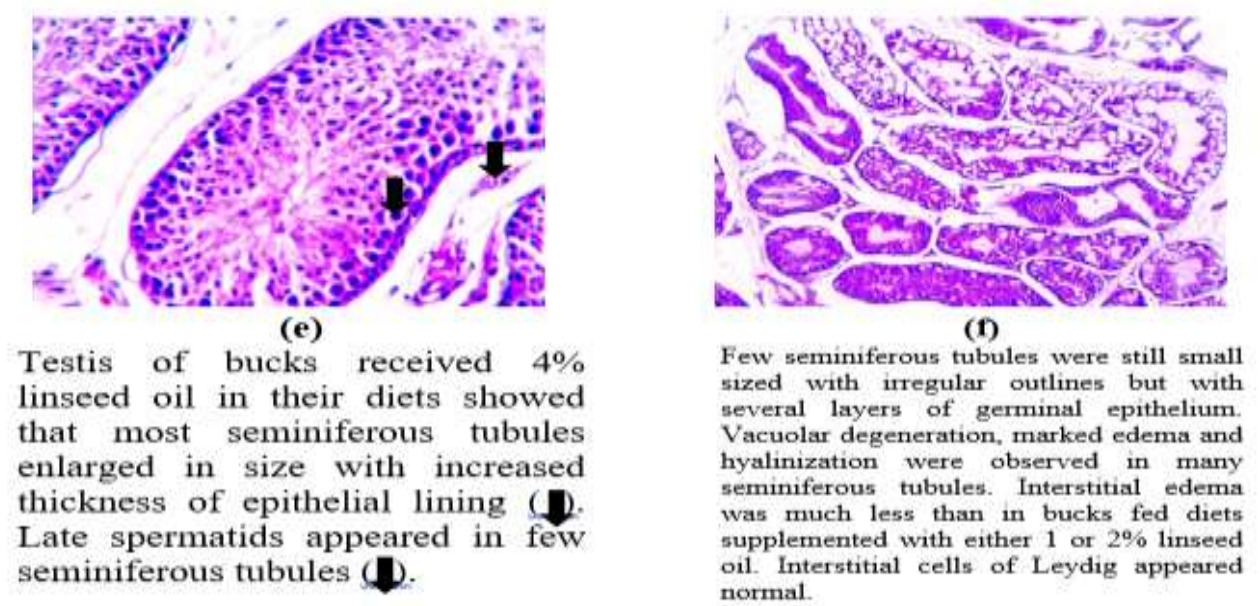

Figure 4: Testes changes in rabbits fed different levels of linseed oil during the experimental period (X400).

The histological changes in testes obtained in the present study are in harmony with the results obtained by Ahmed et al. (2012) who reported that the seminiferous tubules of the rabbit testis at 12 weeks of age were lined by a stratified germinal epithelium characterized by the first appearance of the round spermatids in addition to spermatogonia and spermatocytes. Moreover, seminiferous tubules were observed as solid cords without a central lumen until the $8^{\text {th }}$ week of postnatal development. Lumination of the rabbit testicular cords was demonstrated after 12 postnatal-weeks when the diameter of the seminiferous tubules significantly increased. They added that prespermatogenic or gonocytes, the only germ cells seen, were located in the center of the seminiferous cords and surrounded by the Sertoli cells. Similar observation was seen in the sheep testis (Herrera-Alarcon et al., 2007). Moreover, Li et al. (2017) reported that rams' testes from the linseed oil (LO) group showed a compact and regular arrangement of germ cells and elongated spermatozoids in their seminiferous epithelium. Control group showed vacuolation of seminiferous epithelium. They added that morphology of the tested rams' testes showed that LO also stimulated spermatogenesis with five or more layers of different stages of germ cells in their seminiferous epithelium, which resulted in the seminiferous tubules with bigger diameter than that in the controls. Moreover, regarding testes weight, they found also similar trend to that obtained in Table 4, since they recorded greater testes weight in the LO group than that in the controls. 
Yan et al. (2013) reported that intake of an appropriate n-3/n-6 PUFA ratio in the diet of rats increased sperm characteristics and enhanced the structure integrity of testis and sperm. In addition, Abu-Heakal et al. (2017) found that the highest tubular diameter was in bucks supplemented with $1 \%$ linseed oil after $16 \& 32$ weeks age. The longest lumen diameter and the highest thickness of interstitial tissue were obtained in omega-3 capsule group and $2 \%$ linseed oil group during both testing times, respectively. Meanwhile, the height of germinal epithelium was the longest in control group during both experimental times.

Conclusively, on the light of the aforementioned results, it could be concluded that addition of linseed oil to growing rabbit diets at the rate of 2 followed by $3 \%$ resulted in better feed utilization in forms of lowering daily feed intake accompanied by improved feed conversion ratio and increase in body weight gain without adverse effects on hematological aspects. Moreover, the same treatment induced the most noticeable changes in carcass characteristics as well as structural changes in the histology of both liver and testis of male rabbits.

\section{REFERENCES}

Abdukeyum, G.G., Owen, A.J. and McLennan, P.L. (2008). Dietary (n-3) long-chain polyunsaturated fatty acids inhibit ischemia and reperfusion arrhythmias and infarction in rat heart not enhanced by ischemic preconditioning. J. Nutr., 138: 1902-1909.

Abdulkareem, Hanan, B.G. (2011). Studies on the fortification of rabbit meat with organic Selenium and vitamin E and their effects on antioxidative status and immune response in growing rabbits. M.Sc. Thesis, Fac. Agric. (Saba Basha), Alexandria University, Egypt.

Abu-Dief, Eman E., Doha S. Mohammed, Nesreen G. Abd El-Haliem, Sherine A. Mohammed and El-Badry, A.M. (2018). Impact of omega-3 fatty acids on evolution of carbon tetrachloride-(CCl4) induced liver cirrhosis in mice: A histological and immunohistochemical study. The Egyptian Journal of Histology, 41(1): 61-72.

Abu-Heakal, N., Elseady, Y., Mohamed, A.El., Walaa Awadin and Nada M.A. Hashem (2017). Impact of omega 3 and linseed oil on male fertility in rabbits. Mans. Vet. Med. J., 70 XDII (2), February 2017: 221-233. 
Ahmed, Y.A., Abd-Elhamied, M.M. and Ali, G.K.M. (2012). Histological and Histomorphometric Changes of the Rabbit Testis During Postnatal Development. Research Journal of Veterinary Sciences, 5(2): 42-50.

Anderson, E.J., Thayne, K.A., Harris, M., Shaikh, S.R., Darden, T.M., Lark, D.S., Williams, J.M., Chitwood, W.R., Kypson, A.P. and Rodriguez, E. (2014). Do fish oil omega-3 fatty acids enhance antioxidant capacity and mitochondrial fatty acid oxidation in human atrial myocardium via PPAR $\gamma$ activation? Antioxid. Redox Signal., 21: $1156-1163$.

Attia, Y.A., Abd El-Hamid, A.E., de Oliveira, M.C., Kamel, K.I., Qota, E.M., Al-Harthi, M.A. and Sadaka, T.A. (2018). Soya lecithin and season affect the productive performance, nutrient digestibility, and blood constituents of growing rabbits. Journal of Animal and Feed Sciences, January 2018 (In press). DOI: 10.22358/jafs/80344/2018.

Baldini, M., Giovanardi, R. and Vannozzi, G.P. (2000). Effects of different water availability on fatty acid composition of the oil in standard and high oleic sunflower hybrids. In: Proceedings of the $15^{\text {th }}$ International Sunflower Conference, 2000, Toulouse, France. Toulouse, France: ISA. pp. 79-84.

Bancroft, J.D., Layton, C. and Suvarna, S.K. (2013). Bancroft's theory and practice of histological techniques, $7^{\text {th }}$ edition, Oxford: Churchill Livingstone Elsevier.

Belury, M.A. (2002). Dietary conjugated linoleic acid in health: physiological effects and mechanisms of action. Annual Reviews of Nutrition, 22: 505-531.

Bielanski, P. and Kowalska, D. (2008). Use of linseed oil and antioxidant (vitamin E) in rabbit diets to improve dietetic traits of rabbit meat. In Proceeding $9^{\text {th }}$ World Rabbit Congress, 10-13 June, Verona. Italy. 13191323.

Calvani, M. and Benatti, P. (2003). Polyunsaturated Fatty Acids (PUFA). Sigma tau SPA Sci. Dept. pp. 11-26. Available on: http://www.sths.com/TMA_Forum/PUFA\%20-20Calvani\%20Benatti\%20-\%20 Feb\%202K3.pdf.

Cavani, C., Petracci, M., Trocino, A. and Xiccato, G. (2009). Advances in research on poultry and rabbit meat quality. Ital. J. Anim. Sci., 8 (Suppl 2): 741-750.

Celebi, S. and Utlu, N. (2004). Laying performance, serum lipoproteins, cholesterol and triglyceride of hens as influenced by dietary fat sources. J. Appl. Anim. Res., 25: 121-124. 
Corino, C., Filetti, F., Gambacorta, M., Manchisi, A., Magni, S., Pastorelli, G., Rossi, R. and Maiorano, G. (2003). Influence of dietary conjugated linoleic acids (CLA) and age at slaughtering on meat quality and intramuscular collagen in rabbits. Meat Sci., 66: 97103.

Corino, C., Mourot, J., Magni, S. Pastorelli G. and F. Rosi (2002). Influence of dietary conjugated linoleic acid on growth, meat quality, lipogenesis, plasma leptin and physiological variables of lipid metabolism in rabbits. J. Anim. Sci., 80: 1020-1028.

Corino, C., Lo Fiego, D.P., Macchioni, P., Pastorelli, G., Di Giancamillo, A., Domeneghini, C. and Rossi, R. (2007). Influence of dietary conjugated linoleic acids and vitamin $\mathrm{E}$ on meat quality, and adipose tissue in rabbits. Meat Science, 76: 19-28.

Crowley, H., Lewis, W.D., Gordon, F., Jenkins, R. and Khettry, U. (2000). Steatosis in donor and transplant liver biopsies. Hum. Pathol., 31: 1209-1213.

Dalle Zotte, A. (2002). Perception of rabbit meat quality and major factors influencing the rabbit carcass and meat quality. Review. Liv. Prod. Sci., 75: 11-32.

Delgado, R. (2017). Effect of arginine and glutamine supplementation, dietary soluble fibre level and n-6/n-3 fatty acid ratio on rabbit performance and intestinal health. Doctoral dissertation, Polytechnic University of Madrid, Madrid, Spain.

Duncan, D.B. (1955). Multiple range and multiple F- test. Biometrics, 11: 1- 42.

El-Desoky, A.El.M.I., El-Deeb, M.M., Elseady, Y., Alazab, A.M. and ElSawy, M.A. (2018). Effects of adding linseed oil to rabbits does' diets on some productive and reproductive performance traits. Egyptian Journal of Rabbit Science, 28 (2): 223 -239.

El-Moghazy, M.M., El-Gogary, M.R., Afaf El-Atrsh and Tousson, E. (2014). Effect of supplemental fish oil on histological structure of some organs and blood parameters in NZW rabbits. Biomedicine and Preventive Nutrition, 4 (3): July 2014. DOI: 10.1016/j.bionut. 2014.03.005

FAO/WHO (1994). Fats and oils in human nutrition. FAO, pp: 1-147.

Flachowsky, G., Langbein, T., Bohme, H., Schneider, A. and Aulrich, K. (1998). Effect of false flax expeller combined with short-term vitamin E supplementation in pigs feeding on fatty acid $p$ attern, vitamin $E$ concentration and oxidative stability of various tissues. J. Anim. Physiol. Anim. Nutr., 78: 187-195. 
Herrera-Alarcon, J., Villagomez-Amezcua, E., Gonzalez-Padilla, E. and Jimenez-Severiano, H. (2007). Stereological study of postnatal testicular development in Blackbelly sheep. Theriogenology, 68: 582591.

Li, W., Tang, D., Li, F., Tian, H., Yue, X., Li, F., Weng, X., Sun, W., Wang, W. and Mo, F. (2017). Supplementation with dietary linseed oil during peri-puberty stimulates steroidogenesis and testis development in rams. Theriogenology, 102: 10-15.

Marounek, M., Skrivanova, V., Dokoupilova, A., Czauderna, M. and Berladyn, A. (2007). Meat quality and tissue fatty acid profiles in rabbits fed diets supplemented with conjugated linoleic acid. Veterinarni Medicina, 52 (12): 552-561.

Miezeliene, A., Alencikiene, G., Gruzauskas, R. and Barstys, T. (2011). The effect of dietary selenium supplementation on meat quality of broiler chickens. Biotechnol. Agron. Soc. Environ., 15 (S): 61-69.

NRC (1977). Nutrient Requirements of Rabbits. National Academic of Scienc e. Washington DC, USA.

Okab, A.B., Nasser, T.M., Sabah G. El-Banna, Ayoub, M.A., Samara, E.M. and Al-Haidary A.A. (2017). Can feed supplementation of the refined vegetable oils enhance the seminal quality of rabbit bucks (Oryctolagus cuniculus)? Anim. Reprod., 14(4): 1014-1023.

Omer, H.A.A., Abedo, A.A., Sawsan M. Ahmed, Azza M.M. Badr and Mervat S.M. Hasanin (2013). Utilization of Flaxseeds (Linum usitatissimum L.) in Rabbit Rations. 1. Response of Growing Rabbits to Diets Containing Different Levels of Flaxseeds. Life Science Journal, 10(4): 2638-2646.

Peiretti, P.G. (2012). Effects of dietary fatty acids on lipid traits in the muscle and perirenal fat of growing rabbits fed mixed diets. Animals, 2: 55-67.

Peiretti, P.G. and Meineri, G. (2008). Growth performance, carcass characteristics, and the fat and meat fatty acid profile of rabbits fed diets with chia (Salvia hispanica L.) seed supplements. Meat Sci., 80: 1116-1121.

Qiu, Y.D., Wang, S., Yang, Y. and Yan, X.P. (2012). Omega-3 polyunsaturated fatty acids promote liver regeneration after $90 \%$ hepatectomy in rats. World J. Gastroenterol., 18: 3288-3295.

Rhainds, D. and Brissette, L. (2004). The role of scavenger receptor class B type I (SR-BI) in lipid trafficking. defining the rules for lipid traders. Int. J. Biochem. Cell. Biol., 36: 39-77. 
Rizos, E.C.; Ntzani, E.E.; Bika, E.; Kostapanos, M.S. and Elisaf, M.S. (2013). Association between omega-3 fatty acid supplementation and risk of major cardiovascular disease events. JAMA J., 308(10):10241033.

Rodríguez, María F. (2017). Consequences of dietary supplementation with n-3 polyunsaturated fatty acids on reproductive, endocrine and metabolic parameters of rabbit does and on carcass quality of growing rabbits. Ph.D. Thesis, Universidad Politécnica de Madrid. https://doi.org/ 10.20868/UPM.thesis.49228.

Salama, Maha, F.A. (2011). Studies on the possibility of producing n-3 enriched rabbit meat. M.Sc. Thesis, Fac. Agric. (Saba Basha), Alexandria University, Egypt.

Saleh, A., Ebeid, T.A. and Eid, Y.Z. (2013). The Effect of Dietary Linseed Oil and Organic Selenium on Growth Performance and Muscle Fatty Acids in Growing Rabbits. Pak. Vet. J., 33(4): 450-454.

SAS (2000). User's Guide: Statistics, Version 8.1. SAS Institute Inc. Cary, NC

Scheideler, S.E. (1998). Use of degummed flaxseed in layer diets. Proc. Flax Inst.: 32-34.

Simopoulos, A.P. (2000). Human requirement for n-3 polyunsaturated fatty acids. Symposium: role of poultry products in enriching the human diet with n-3 PUFA. Poultry Science, 79: 961-970.

Simopoulos, A.P. (2008). The importance of the omega-6/omega-3 fatty acid ratio in ardiovascular disease and other chronic diseases. Exp. Biol. Med., 233: 674-688.

Sugasini, D. and Lokesh, B.R. (2017). Curcumin and linseed oil co-delivered in phospholipid nanoemulsions enhances the levels of docosahexaenoic acid in serum and tissue lipids of rats. PLEFA; 119: $45-52$

Trebušak, T., Levart, A., Voljč, M., Tomažin, U. and Pirman, T. (2011). The effect of linseed oil supplementation on performance, fatty acid composition and oxidative status of rabbits. Acta Argiculturae Slovenica, 98 (2): 119-125.

Vieira, S.L., Viola, E.S., Berres, J., Coneglian, J.L.B., Freitas, D.M. and Bortolini, T.C.K. (2006). Water intake and digestive metabolism of broilers fed all-vegetable diets containing acidulated soybean soapstock. Braz. J. Poult. Sci., 8: 159-165.

Wathes, D.C., Abayasekara, D.R.E., Aitken, R.J. (2007). Polyunsaturated fatty acids in male and female reproduction. Biol. Reprod., 77: 190201. 
Whitney, M.B., Hess, B.W., Burgwald-Balstad, L.A., Sayer, J.L., Tsopito, C.M., Talbott, C.T. and Hallford, D.M. (2000). Effects of supplemental soybean oil level on in vitro digestion and performance of pre-pubertal beef heifers. J. Anim. Sci., 78: 504-514.

Yan, L.; Bai, X.L.; Fang, Z.F.; Che, L.Q.; Xu, S.Y. and Wu, D. (2013). Effect of different dietary omega-3/omega-6 fatty acid ratios on reproduction in male rats. Lipids Health Dis., 12: 33-41.

Zeweil, H.S., Zahran, S.M., Ahmed, M.H., El-El-Gindy, Y. and Shaglouf, W.G.M. (2016). Effects of allicin and lycopene on performance, carcass, hematological profile and antioxidant status of growing rabbits through summer season. Journal of the Advances in Agriculture Research, 21(4): 622-637.

Zhang, X., Wang, H., Yin, P., Fan, H., Sun, L. and Liu, Y. (2017). Flaxseed oil ameliorates alcoholic liver disease via anti-inflammation and modulating gut microbiota in mice. Lipids Health Dis., 16: 44-53.

\section{التأثير الغذائي لزيت الكتان على الكفاعة الإنتاجية وصفات الأبيحة وصورة الام للأرانب النامية الإنة

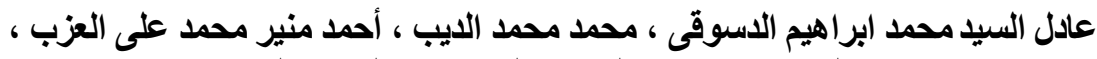 معهد بحوث الإنتاج الحيواني ، مركز البحوث الزر اعية ، الدقي ، الجيزة ، مصر.}

شملت الدراسة عدد ، م أرنب نيوزيلندي أبيض نامي بعمر ه أسابيع ومتوسط

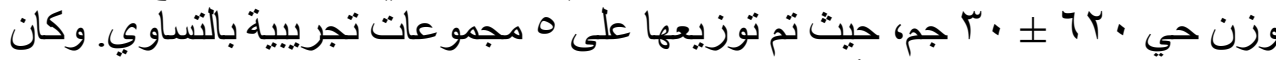

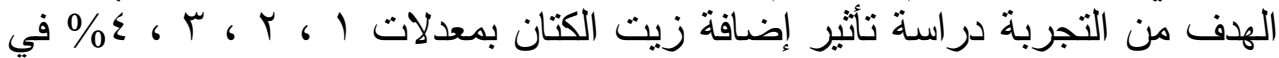

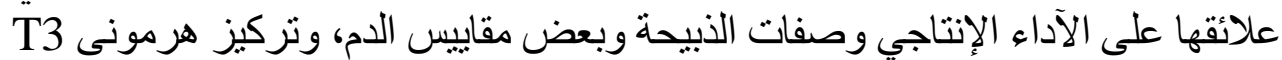
، T4 ، وكذلك دراسة هستولوجية شملت التغيرات التركيبية في الكبد و الخصيتين هيني للحيو انات المختبرة.

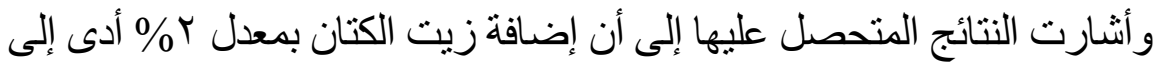

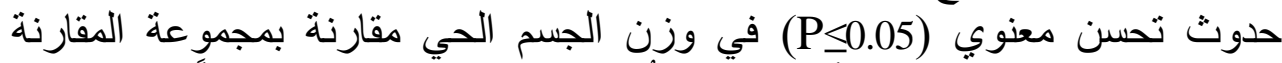

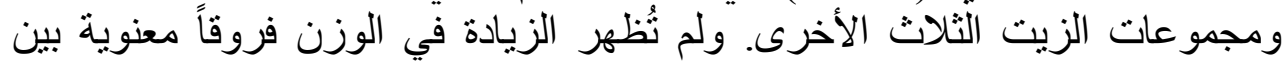

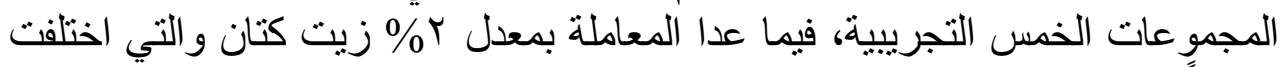
معنوياً (P\0.05) مقارنة بالمسجلة في مجموعة المقارنة و الثلاث مجمو عات آلتجريبية 


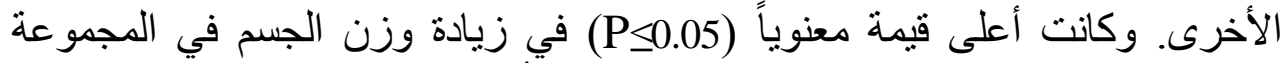

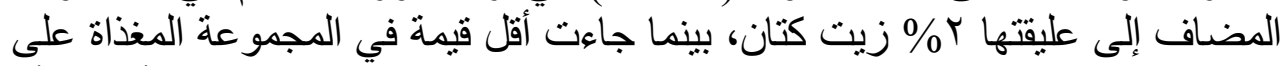

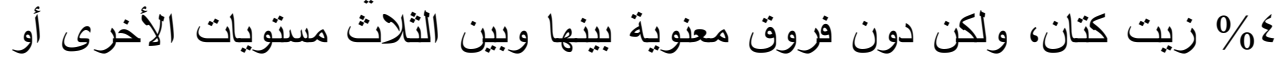

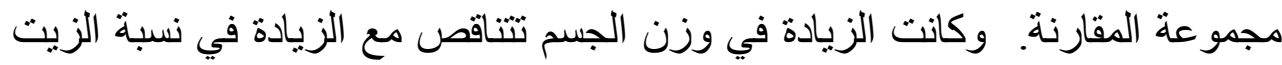
المضاف في العليقة. انخفضت كمية المأكول اليومي مقارنة بتلك المسجلة في مجموعة المقارنة مع المعان

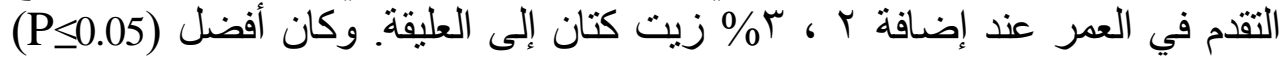

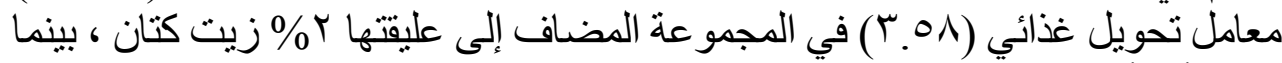

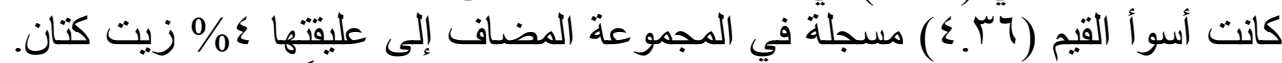

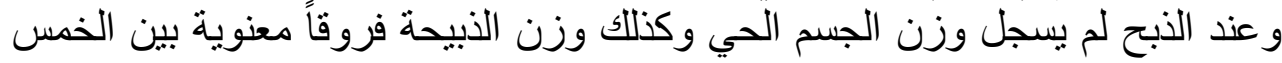

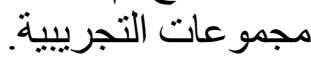
أدت إضافة زيت الكتان إلى علائق الأرانب المختبرة إلى تحسن وزن الذبة الذبيحة

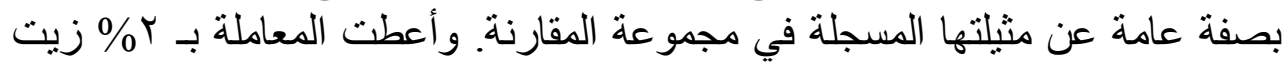

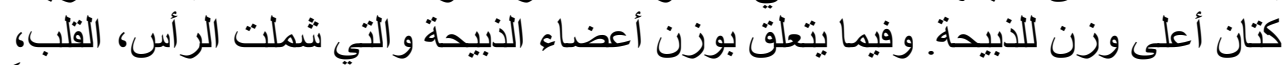

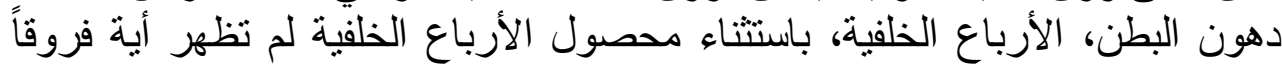

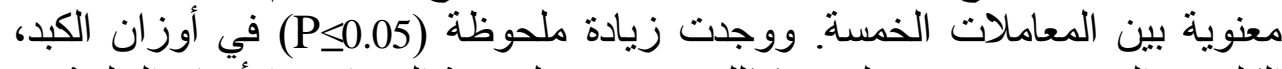

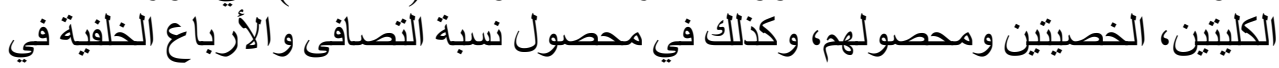

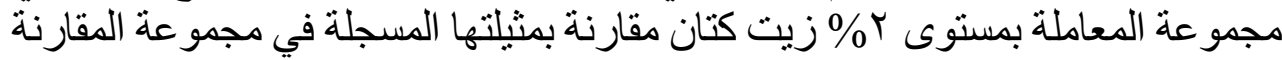
ومستويات الإضافة الثثلاث الأخرى. أدت إضافة زيت الكتان بصفة عامة إلى زيادة قيم البروتين الكلي، الألبيومين،

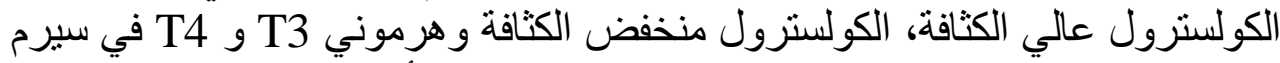

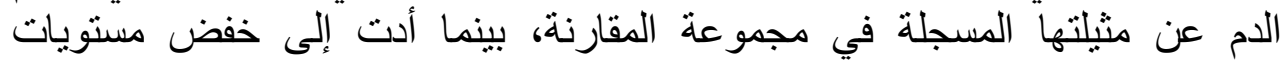
الجلوبيولين والكولسترول الكلي والدهون الثثلاثية مع المستويات العالية من الزيت التيت

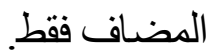

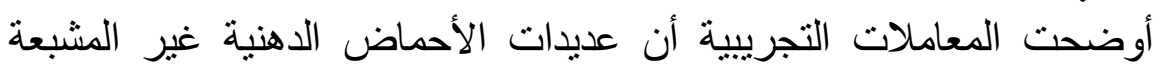

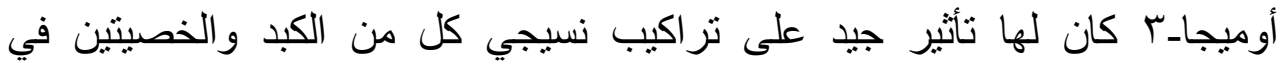

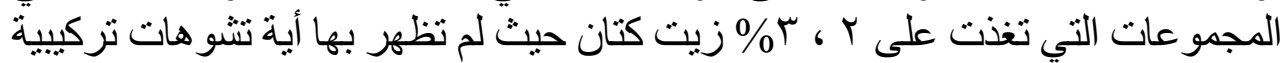
في أنسجة كلا العضوين.

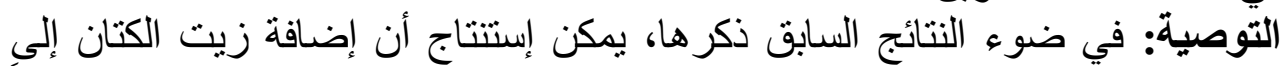

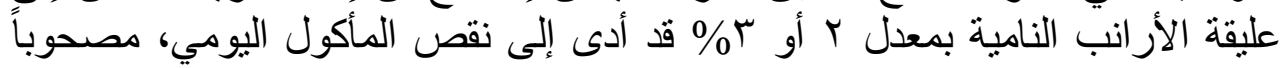

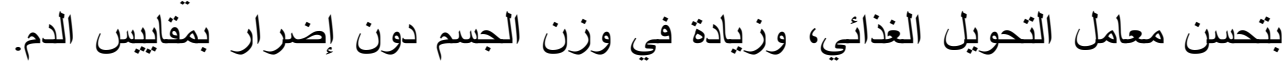

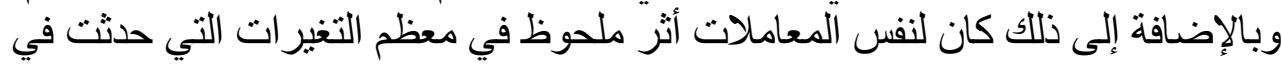
خصائص الذبيحة، وكذللك التغيرات التركيبية في نسيج كل من الكبد والخيل الخصيتين للذكور. 